\title{
СУЧАСНІ УЯВЛЕННЯ ПРО РОЗВИТОК ОСТЕОАРТРОЗУ, МЕТОДИ ДІАГНОСТИКИ І ЛІКУВАННЯ
}

\author{
О. О. Борейко \\ Тернопільський національний медичний університет \\ імені І. Я. Горбачевського МОЗ Украӥни
}

\begin{abstract}
У статті розглянуто загальні відомості та клінічні прояви остеоартрозу, сучасні підходи до його лікування. Крім того, здійснено спробу визначити сутність комплексного підходу до лікування i реабілітації хворих на остеоартроз. Проаналізовано проблему лікування та реабілітації населення України з дегенеративними захворюваннями опорно-рухового апарату, яка залишається невирішеною. Здійснено аналіз та доведено, що «симптоматичне» та «базове» лікування остеоартрозу не повністю відновлює функціональну активність, а в довгостроковій перспективі призводить до прогресування дегенеративного процесу. Крім того, аналіз результатів нашого дослідження показав, що формально призначене лікування спричиняє великі та безглузді витрати бюджетних коштів та надає пацієнтам впевненості в ефективності лише хірургічних методів лікування.
\end{abstract}

\section{MODERN IDEAS ABOUT THE DEVELOPMENT OF OSTEOARTHRITIS, METHODS OF ITS DIAGNOSIS AND TREATMENT}

\author{
0. O. Boreyko
}

\section{Horbachevsky Ternopil National Medical University}

\begin{abstract}
The article considers general information and clinical manifestations of osteoarthritis, modern approaches to the treatment of osteoarthritis. In addition, we tried to determine the essence of a comprehensive approach to the treatment and rehabilitation of patients with osteoarthritis. The problem of treatment and rehabilitation of the population of Ukraine with degenerative diseases of the musculoskeletal system, which remains unresolved. The analysis is carried out and it is proved that everywhere "symptomatic" and "basic" treatment of osteoarthritis does not completely restore functional activity, but in the long run leads to the progression of the degenerative process. In addition, the analysis of the results of our study found that formally prescribed treatment causes large and pointless spending of budget funds and gives patients confidence in the effectiveness of only surgical treatments.
\end{abstract}

Вступ. Остеоартроз (OA) - це найпоширеніше захворювання суглобів з ураженням як великих, так і дрібних суглобів. Початок остеоартрозу провокується дуже різними факторами, включаючи порушення розвитку, обміну речовин та суглоба, але в будь-якому випадку до патологічного процесу залучаються всі тканини суглоба, особливо страждає хрящова тканина.

Суглобовий хрящ, що покриває суглобові поверхні кісток, досить зносостійкий та еластичний, щоб пом'якшити удари, і досить слизький, щоб запобігти тертю однієї кістки об іншу. Це можливо завдяки унікальній структурі хрящової тканини: в желеподібній

(c) О. О. Борейко, 2021 субстанції, утвореній глікозаміногліканами, розташовані волокна сполучної тканини. Завдяки матриксу відбувається живлення хряща і відновлення ушкоджених волокон. Подібна структура робить хрящ схожим на губку - в спокійному стані він поглинає рідину, а при навантаженні штовхає її в порожнину суглоба, щоб забезпечити «мастило» для суглобових поверхонь. Зазвичай процеси утворення (синтезу) та руйнування (деградації) збалансовані при спільному вдосконаленні.

Стійка капсула, що обмежує порожнину суглоба, складається з двох оболонок: зовнішньої фіброзної та внутрішньої синовіальної. Синовіальна оболонка транспортує поживні речовини для хряща, позбавленого судин. 
Протягом життя хрящ гнучко реагує на стереотипні, повторювані удари при деяких видах роботи або бігу, стрибків тощо. Таке постійне навантаження призводить до старіння та руйнування деяких волокон, які в здоровому суглобі заповнюються синтезом такої ж кількості нових волокон. Вважають, що остеоартроз $є$ наслідком механічних і біологічних факторів, що спричиняють недостатнє формування або посилений розпад хрящової тканини, що призводить до втрати очищення нормальної щільності та структури, що викликає порушення функції суглобів. На сьогодні остеоартроз розглядають не просто як наслідок старіння та дегенерації хряща, а як результат активних процесів, багато з яких за своєю суттю $є$ запальними.

Основна частина. Характерною ознакою ушкодження хряща при остеоартрозі $є$ втрата матриксних речовин, що об'єднуються терміном «глікозаміносульфат». Прогресивне зниження вмісту хондроїтинсульфату, кератансульфату та гіалуронової кислоти супроводжується розщепленням волокон і розкладанням матриксу з утворенням поверхневих дефектів та тріщин різної глибини.

Важливу роль у порушенні нормальної структури суглобового хряща відіграє запалення, особливо запалення, що розвивається в хрящі, у внутрішньому шарі суглобової капсули - в синовіальній оболонці суглоба. Особливе значення мають також патологічні процеси, що розвиваються і відбуваються в субхондральній кістці, де можна виявити мікропереломи та зміни ії структури. Кісткові нарости (остеофіти) утворюються по краях суглоба, ніби заповнюючи втрату хряща, збільшуючи суглобові поверхні та кісти (порожнини) в цій частині кістки. Це є причиною деформації суглобів при артрозі. Люди називають цей стан «відкладенням солі».

Справжня причина остеоартрозу досі незрозуміла. Основним фактором розвитку захворювання $\epsilon$ невідповідність між механічним навантаженням на суглобову поверхню хряща та його здатністю витримувати це навантаження.

Факторами ризику розвитку остеоартрозу $\epsilon$ :

- уроджена особливість будови хрящової тканини, що сприяє легшим травмам, а також проявляється плоскостопістю, раннім розвитком остеохондрозу та підвищеною рухливістю суглобів;

- уроджений повний або неповний вивих тазостегнового суглоба;
- жіноча стать: жінки, особливо під час менопаузи, хворіють удвічі частіше, ніж чоловіки;

- вік: поширеність остеоартрозу зростає з віком і сягає максимального рівня у віковій групі старше 45 років;

- ожиріння;

- ендокринні порушення;

- механічні впливи (травми; робота з надмірними навантаженнями на колінні, тазостегнові та інші суглоби; фізичне навантаження).

Остеоартроз може розвинутися в будь-якому суглобі. Насамперед це впливає на суглоби, які несуть максимальне навантаження. Остеоартроз колінних суглобів називають гонартрозом, остеоартроз тазостегнових суглобів - коксартрозом.

Основні клінічні прояви остеоартрозу:

1) біль в уражених суглобах під час навантаження - відбувається раптово, його інтенсивність може варіювати від легкого до помірного, біль посилюється при русі в ураженому суглобі та зменшується в стані спокою;

2) хрускіт в уражених суглобах під час руху;

3) скутість в уражених суглобах (найчастіше з'являється вранці);

4) обмеження рухів в ураженому суглобі - відбувається, коли процес триває через наявність болю та появу рефлекторного спазму м'язів;

5) блокада суглобів - виникає на пізніх стадіях артрозу у вигляді гострого болю, що унеможливлює найменші рухи в суглобі;

6) набряк суглоба - розвивається при сильному запаленні синовіальної оболонки.

Природний перебіг остеоартрозу різний. Незважаючи на рентгенологічний перебіг захворювання, в деяких випадках стан пацієнта залишається стабільним протягом багатьох років, тобто немає сильного болю та запалення або обмеження рухливості.

Після діагностики артрозу на тлі загострення 3 сильним больовим синдромом необхідно стежити за здоров'ям суглобів. Відсутність болю є свідченням відсутності вираженого загострення, але не «лікування» та «полегшення» хвороби. Прогресування процесу спостерігають переважно у пацієнтів із ожирінням, ушкодженням багатьох суглобів та утворенням вузликів у навколосуглобовій тканині.

Діагностика остеоартрозу:

- клінічні прояви (біль, набряк, хрускіт у суглобах тощо); 
- рентгенологічне дослідження (звуження суглобової щілини, поява остеофітів);

- ультразвукове дослідження суглобів.

У патогенезі остеоартрозу розрізняють дві основні послідовні стадіі:

1. Біосинтетична стадія, під час якої переважають процеси відновлення хрящового матриксу. Матрикс суглобового хряща містить дві основні макромолекули - глікозаміноглікани (протеоглікани) та колаген. Умовно цю стадію можна називати стадією компенсації, коли хондроцити ще здатні підтримувати адекватне функціонування хрящової тканини. У разі втрати навіть невеликої кількості глікозаміногліканів, опір матриксу хряща до дії фізичного навантаження зменшується і поверхня хряща стає чутливою до ушкодження.

2. Стадія деградації, зумовлена руйнуванням хрящової тканини на тлі дії ферментів металопротеїназ, продукованих хондроцитами. На цьому етапі порушується рівновага між утворенням нового будівельного матеріалу для відновлення хряща та його руйнуванням, що призводить до незворотних змін.

Таким чином, в основі появи та розвитку остеоартрозу лежать порушення структури та функції хряща.

\section{Клінічна картина}

Основні клінічні ознаки захворювання: біль, обмеження руху, скутість та деформація суглобів, що призводять до функціональної недостатності та зменшення якості життя.

За прогнозами ВООЗ, остеоартроз колінного суглоба буде четвертою причиною інвалідності у жінок та восьмою причиною в чоловіків у найближчі десятиліття. Тому проблема ефективного лікування остеоартрозу колінного суглоба має не тільки медичне та соціальне значення, але й економічне [1].

Походження остеоартрозу колінного суглоба зумовлене низкою факторів: будовою хряща, змінами складу внутрішньосуглобової рідини, в тому числі на клітинному рівні. Все це утворює патологічний комплекс симптомів функціонування колінного суглоба, що характеризує стадії розвитку артрозу коліна. Крім того, кожна стадія має свої морфологічні та функціональні характеристики, що дозволяють диференційовано підходити до вибору тактики лікування [2].

Спираючись на знання етіології, дослідники розробляють сучасні підходи до діагностики та лікування остеоартрозу колінного суглоба, а також пропонують різні класифікації.

За етіологією остеоартроз колінного суглоба поділяють на первинний та вторинний. Первинний остеоартроз колінного суглоба виникає без відомих чи ідентифікованих причин. Якщо є фактори, що провокують руйнування суглоба, розвивається так званий вторинний артроз коліна. Причинами вторинного артрозу є травми. Переважно це внутрішньосуглобові переломи кісток, які утворюють колінний суглоб. Крім того, ушкодження стегнової та гомілкової кісток, а також надколінка, які зрощені в неправильному положенні та, змінюючи анатомомеханічну вісь кінцівки, призводять до порушення конгруентності суглоба, а згодом - до деформації та руйнування суглобового хряща. Запальні агенти трапляються рідше, наприклад артрит, гемартроз та інші патологічні стани, що порушують нормальний гомеостаз синовіальної рідини [3].

Незважаючи на високий інтерес професіоналів до дегенеративних травм колінного суглоба, недостатньо зрозумілий патогенез усіх варіантів розвитку цього захворювання, необхідний для вибору правильної схеми лікування.

Навіть при успішному хірургічному лікуванні ДДС, більшість хірургічних лікарень, що займаються ендопротезуванням, не мають можливості проводити комплексні післяопераційні реабілітаційні заходи з організаційних причин. Як правило, пацієнти змушені самостійно відновлювати функцію проблемного суглоба, лише дотримуючись загальних рекомендацій лікуючого лікаря після виписування [3]. У зв'язку з цим, наукові розробки з проблеми реабілітації, присвячені лікуванню пацієнтів після ендопротезування кульшових суглобів, залишаються неадекватними в амбулаторній практиці, що, безумовно, впливає на віддалені результати ендопротезування. Заходи реабілітації, пропоновані медичними закладами, як правило, обмежуються фізичною терапією, курсами масажу та обмеженою кількістю фізіотерапевтичних процедур $[4,5]$.

Реабілітація має велике, можна сказати, провідне значення у подальшому житті людей із дегенеративними захворюваннями. За допомогою реабілітаційних заходів можна відновити працездатність пацієнта і повернутися до попереднього активного способу життя, а також запобігти багатьом ускладненням, особливо в геронтологічній практиці.

Одним з найпоширеніших дегенеративних захворювань $\epsilon$ остеоартроз [6, 7].

При остеоартрозі в патологічний процес залучаються всі структури органа суглобового руху: гіаліновий хрящ, зв'язки та навколосуглобові м'язи, синовіальна оболонка, субхондральна кістка, кап- 
сула суглоба. Однак у науковій літературі про остеоартроз переважаючий погляд на складний запальний генез «смерті» хряща під час розвитку дегенеративної патології суглобів ігнорував першопричину, таку, як гіпотрофія/атрофія та дисбаланс у функції сегментних м'язів і нестабільність та ії переривчаста макро- або мікронна конгруентність $[6,8]$.

Морфологія гіалінового хряща починає страждати вдруге при дегенеративних захворюваннях після вичерпання пристосованості навколосуглобової тканини [8-10].

Ця думка підтверджується ефективністю адекватного комплексного медикаментозного та немедикаментозного лікування остеоартрозу на ранніх стадіях захворювання, що дає змогу запобігти незворотним змінам гіалінового хряща та продовжити тривалість активного життя людини.

Думка про низьку ефективність консервативного лікування остеоартрозу пов'язана з низькою ефективністю знеболювальної терапії щодо динаміки захворювання та відсутністю раціональної реабілітації після лікування гострого періоду захворювання. 3 цієї причини тотальне ендопротезування великих суглобів стало найефективнішим методом лікування як за кордоном, так і в Україні.

Складні програми, такі, як масаж, лікувальні вправи, лікування термальною водою, різні варіанти електротерапії, лазер, вакуум-компресорна терапія, ерготерапія - це основа реабілітаційних заходів як у рамках консервативного лікування, так і в післяопераційній фазі після ендопротезування. Справедливо вважати, що якість реабілітації становить щонайменше 50 \% успіху ендопротезування та консервативного лікування - тривалість ремісії та уповільнення прогресування захворювання [1, 4, 11, 12].

Надзвичайно важливим аспектом лікування та подальшої реабілітації синдрому хронічного суглоба, особливо в геронтологічній практиці, $є$ навчання пацієнта навичкам та повсякденній діяльності. Для багатьох наших пацієнтів зі стійкими морфологічними змінами в структурі суглобів найпростіші елементарні рухи вже недоступні. Страх і очікування болю, контрактур або гіпермобільності суглоба ускладнюють ходьбу, повороти в ліжку, сидячи або встаючи зі стільця та ліжка. Таким пацієнтам потрібні групові та індивідуальні сеанси для відновлення щоденних фізичних навантажень [6]. На жаль, практика проведення шкіл для хворих на остеоартроз не виправдала наших сподівань: як правило, до класу приходять одні й ті ж пацієнти, а не завжди ті, для кого школа справді актуальна. Головним секретом успішної реабілітації є вміле поєднання лікувальних та реабілітаційних заходів із застосуванням нових і класичних методик, основаних на науково підтверджених даних та справжньому бажанні допомогти пацієнту. На сьогодні великі клініки успішно впроваджують метод терапії ботоксом - використання ботулотоксину для зняття спастичних уражень при ОА та озонотерапії шляхом введення озону в болючі м'язи [3]. Все частіше гірудотерапію (лікування п'явками) застосовують при консервативному лікуванні та реабілітації OA [4].

В останні роки ендопротезування стало одним із найпопулярніших напрямків лікування хворих на артроз великих суглобів. Однак розробці методів та схем післяопераційної медикаментозної терапії не надають необхідного значення в контексті оптимізації реабілітації пацієнтів з ендопротезуванням (в контексті не приділяють належної уваги). Варто зазначити, що література містить дані наукових та клінічних досліджень, спрямованих на розробку безпечних методів фармакотерапії післяопераційного алгічного синдрому, які сприяють прискоренню періоду відновлення після повного ендопротезування. Руденко Я. В. вивчав клінічну ефективність препарату «Артрофон» після тотального ендопротезування великих суглобів. Виявлено, що група пацієнтів, які приймали цей препарат, мала кращі результати, ніж контрольна група пацієнтів, які його не отримували. Крім того, не спостерігали жодного випадку погіршення стану в тих, хто приймав Артрофон, тоді як два з двадцяти таких пацієнтів мали місце в контрольній групі. Жоден із пацієнтів не мав побічних ефектів від цього препарату.

Таким чином, застосування препарату «Артрофон» при лікуванні ОА підвищує ефективність терапії навіть після хірургічного лікування суглобів. Забезпечення лікувального ефекту досягається поєднанням препарату «Артрофон» з іншими протизапальними препаратами для посилення протизапальної та знеболювальної дії, мінімізації використання інших препаратів та попередження ускладнень, викликаних цими препаратами. Найчастіше Артрофон поєднують з хондропротекторами, що значно підвищує ефективність та безпеку медикаментозної терапії при суглобовому синдромі [2].

Основним моментом застосування хондропротекторів $є$ структурний компонент хрящової тканини. 
Впливаючи на метаболізм цих речовин, хондропротектори регулюють обмінні процеси в хрящі, уповільнюють їх руйнування та активізують їх регенерацію. Метою використання хондропротекторів $\epsilon$ нормалізація білкового складу хряща, прискорення його відновлення після ушкодження або зупинка процесу його руйнування. Спільне застосування хондропротекторів та препарату «Артрофон» надає легкий метаболічний та протизапальний ефект на суглобові компоненти в процесі лікування та реабілітації, зменшуючи прояви суглобового синдрому та покращуючи якість життя.

Аспект навчання пацієнта про ортопедичну поведінку в гострий період надзвичайно важливий. У цей час необхідно обмежити всі рухи, що збільшують навантаження на суглоб. Повністю виключити підняття та носіння тягарів. Жінкам рекомендують відмовитися від взуття на підборах більше 3-4 см. У разі остеоартрозу колінного суглоба пацієнту рекомендують сідати на високі стільці. Необхідно встати з положення сидячи з опорою на руки і перемістити центр ваги до краю стільця. Це полегшує процес підняття і зменшує навантаження на суглоб. Поінформованість пацієнта про наявність остеоартрозу та розуміння правил поведінки дозволяють не боятися цього діагнозу і вести повноцінне життя. При ОА нижніх кінцівок пацієнтам необхідно уникати фіксованих поз, які перешкоджають припливу крові до хворих суглобів. Такі пози - це, наприклад, положення «навприсядки», сидячи на невисокому дивані або в кріслі. Необхідно чергувати періоди фізичних навантажень з періодами відпочинку. У гострій фазі тривала ходьба без перерв протипоказана. Після кожних 20 хв вертикальних вправ бажано відпочивати в сидячому положенні.

Фізіотерапія у гострій фазі також має свої особливості. Фізіотерапевтичні вправи, звичайно, повинні мати індивідуальний характер, враховуючи як фізичну форму конкретного пацієнта, так і особливості супутнього захворювання. Виконувати вправи потрібно повільно і плавно сидячи або лежачи, поступово збільшуючи обсяг рухів. Необхідно виключити різкі рухи і вправи, що викликають сильний біль. Основним принципом, якого повинен дотримуватись пацієнт, $є$ поступовість і регулярність викладання.

Вправа повинна створити відчуття легкої втоми. якщо біль у суглобах виникає і триває під час фізич- них вправ, кількість повторень має бути зменшена. Оптимальний для гострого періоду артикульованого синдрому $є$ терапевтичні вправи в басейні з теплою водою, наприклад Aqua-aerobic. Оскільки маса тіла у воді зменшується більш ніж у п'ять разів, рухи в суглобах менш травматичні. Варто зазначити, що не існує вікових обмежень для медичної гімнастики. На додаток до позитивного впливу на симптоми ОА, фізична активність допомагає зміцнити серце, кровоносні судини та кістки.

Наприкінці гострої фази рекомендують нешвидко перейти на помірний темп. Це чудовий спосіб зміцнити і підтримувати м'язовий тонус. Рекомендують 30-хвилинні щоденні прогулянки. Регулярна достатня фізична активність збільшує поглинання поживних речовин у синовіальну рідину через хрящі близько 3-4 рази і позитивно впливає на м'язи та кровообіг. Регулярні вправи зміцнюють м'язи ураженого сегмента, що, у свою чергу, утворює м'язовий корсет і покращує підтримку функції кінцівки.

Успішне завершення лікування вимагає життя пацієнта на рівні набутих морфологічних змін у суглобі без ознак їх прогресування.

Висновки. Проблема лікування та реабілітації населення України з дегенеративними захворюваннями опорно-рухового апарату залишається невирішеною проблемою. Ентузіазм до медикаментозної терапії на ранніх стадіях захворювання, переважно протизапальних, а потім і на пізніх стадіях - хірургічне лікування ґрунтується на тому, що дегенеративну патологію в амбулаторній системі лікують фахівці, які не розуміють ролі біомеханічних зв'язок. «Симптоматичне» та «базове» лікування не повністю відновлює функціональну активність, але в довгостроковій перспективі призводить до прогресування дегенеративного процесу. Формально призначене лікування спричиняє великі та безглузді витрати бюджетних коштів та надає пацієнтам впевненості в ефективності лише хірургічних методів лікування. Існуюча думка, що найдосконалішим та найефективнішим методом лікування деформуючого остеоартриту $є$ повна артропластика ураженого суглоба, ще більше міфологізує цю довіру населення. На сьогодні в усьому світі накопичений великий досвід впровадження ендопротезування та післяопераційного лікування таких пацієнтів. Цей метод широко використовують і в Україні. 


\section{СПИСОК ЛІТЕРАТУРИ}

1. Рыбачук О. И. Искусственный тазобедренный сустав: пособие для врачей / О. И. Рыбачук, А. В. Калашников. K., 2000. -88 c.

2. Woolfe F. D. Burden of major musculoskeletal conditions / F. D. Woolfe, B. Pfleger // Bull. World Organ. 2003. - Vol. 81. - P. 646-564.

3. Increasing prevalence of knee pain and symptomatic knee osteoarthritis. Paper presented at: American College of Rheumatology Association of Rheumatology Health Professionals Annual Scientific Meeting / U. D. T. Nguyen, Y. Zhang, J. Niu [et al.]. - Atlanta, GA., 2010.

4. Van den Berg W. B. Pathophisiology of osteoarthritis / W. B. Van den Berg // Joint Bone Spine. - 2000. - Vol. 67. P. 555-556.

5. Кораблева Н. Н. Комплексное лечение и реабилитация больных с дегенеративными заболеваниями суставов. Взгляд реабилитолога / Н. Н. Кораблева // Поликлиника. - 2014. - № 2. - С. 38-41.

6. Головач И. Ю. Остеоартрит: фундаментальные и прикладные аспекты этиопатогенеза заболевания. Ничего не стоит на месте / И. Ю. Головач // Український ревматологічний журнал. - 2014. - № 2 (56). - С. 4-11.
7. Зайцева Е. М. Причины боли при остеоартрозе и факторы прогрессирования заболевания / Е. М. Зайцева, Л. И. Алексеева // Научно-практическая ревматология. 2011. - № 1. - С. 50-57.

8. Іскра Н. І. Особливості комплексного лікування хворих з верифікованим діагнозом «Остеоартроз» / Н. І. Іскра, Я. С. Кукуруз, В. Ю. Кузьмін // Ліки України. 2011. - № 6. - С. 115-117.

9. Коваленко В. М. Ревматичні захворювання в Україні: стан проблеми та шляхи вирішення / В. М. Коваленко // Український ревматологічний журнал. - 2012. - № 3 (49). C. 84-86.

10. Національний підручник з ревматології / за ред. В. М. Коваленка, Н. М. Шуби. - К. : Моріон, 2013. - 672 с. : іл., табл., бібліогр.

11. Раскина Т. А. Новый взгляд на проблему терапии остеоартроза / Т. А. Раскина, М.В.Летаева // Современная ревматология. - 2012. - № 4. - С. 86-89.

12. Чичасова Н. В. Лечение хронических заболеваний суставов / Н. В. Чичасова // Современная ревматология. 2012. - № 2. - С. 89-98.

Отримано 27.04.21 